\title{
OBITUARIES
}

\section{CLIFFORD EVANS, 1920-1981}

Clifford Evans died suddenly of a heart attack on January 19,1981 . His passing sent shock waves through the Smithsonian Institution, where he had served ably for 30 years, and throughout North and South America where his scholarly and administrative acumen had contributed so much and helped so many over the years.

Clifford Evans was born on June 13, 1920, in Dallas, Texas, the oldest child of Clifford and Pearl Weiss Evans. After his father's death when Cliff was 6 years old the family moved to San Bernardino, California. By the time he was 9, Cliff had decided he wanted to become an archaeologist, much to the bewilderment of his schoolmates who thought him odd or called him "Ditch Digger." Cliff attended Sturgis Junior and San Bernardino Union Senior high schools and in 1937 he entered San Bernardino Valley Union Junior College where he studied zoology, botany, and geology in preparation for his planned career in archaeology. He also mowed lawns and managed the school bookstore to support his college studies. In 1939 Cliff received an Associate of Arts degree from the junior college and enrolled as an anthropology major at the University of Southern Cali-

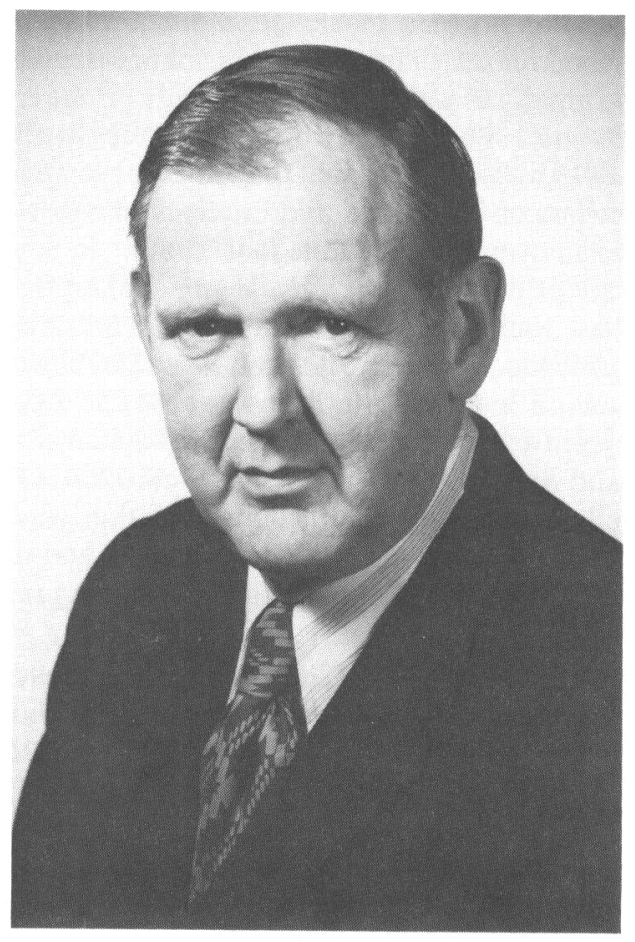
fornia. In the summer of 1940 he, together with classmate George Kepler Lewis, attended the University of Arizona archaeological fieldschool at Forestdale, directed by Emil Haury.

After graduation from USC, Evans worked for the Lockheed Aircraft Corporation in Los Angeles; with the advent of World War II he joined the United States Army Air Corps, becoming a Second Lieutenant and B-17 bombardier. In 1944 he was sent to England. While on his thirteenth mission in 16 days, Cliff's plane was shot down during a raid on Hamburg on June 20, 1944. Bailing out, he landed in a garden near the railroad yards and was nearly killed by a mob of civilians before being rescued by German soldiers. He later wrote that he did not "blame them at all for this airman was the personification of the war." He was shifted through several prison camps. At one he was interrogated by a Luftwaffe officer and was amazed to learn that the Germans had a complete dossier on his life since childhood. He was later placed in a camp in Sagan, Germany. In late January 1945, in below zero weather he and his fellow prisoners were evacuated on foot and later in railroad boxcars to keep them out of the hands of the advancing Soviet army. He spent the remainder of the war in a camp near Moosburg, Germany, ultimately with nearly 50,000 other 
prisoners. The camp was liberated on April 29, 1945, by an element of General George Patton's Third Army.

By June 3 of that year Cliff was being mustered out of the service at Staten Island, New York and in the fall he entered Columbia University to pursue his lifelong aim of becoming an archaeologist. There, he was a student of William Duncan Strong. On an assignment classifying a sherd collection at the American Museum of Natural History, he met a fellow graduate student, Betty Meggers, who was also classifying sherds. Their "romance in the towers" of the Museum culminated in their engagement in January 1946, when Cliff left with Strong for an 8-month field trip to Peru. Cliff and Betty were married in September, 1946, 3 days after Cliff returned from South America.

Thus began a marriage, a partnership and a colleague relationship that deepened and flourished for 35 years. With their characteristic thoroughness Cliff and Betty laid out a 20-year program of research focusing initially on the Amazon Basin in South America. (Poole and Poole 1963; Payne 1968:20). They began their fieldwork on Marajó Island at the mouth of the Amazon in July 1948, where they spent 6 months surveying and testing some 90 village and burial sites and, later, others on Mexicana and Caviona islands and in the Amapá Territory, Brazil. Cliff wrote his doctoral dissertation on the last (1950d). In September 1949, Cliff became an instructor in anthropology at the University of Virginia. While there he undertook a study of local prehistoric ceramics that remains a standard work (1955d). Evans began his 30-year career with the Department of Anthropology, U.S. National Museum (now the National Museum of Natural History) of the Smithsonian Institution in January 1951, as Associate Curator and Archeologist (1951-1962). Subsequently, he became Curator and General and Supervisory Archeologist (1962-1970), Chairman and Supervisory Anthropologist (1970-1975), and Curator, General Archeology (1975-1981). In all respects the Smithsonian position was an ideal one for a person of his temperament and abilities. It gave him the opportunity and the facilities to carry through his and Betty's research programs and to aid others in developing research programs throughout Latin America and North America.

In October 1952, Cliff and Betty returned to the field for an 8-month program of archaeological and ethnological research in British Guiana sponsored by the Smithsonian Institution and the Fulbright Research Scholar Program (1960e). This was followed by a period of active fieldwork in coastal Ecuador (with Emílio Estrada in 1954, 1957, 1958, and 1961), in eastern Ecuador (1956), in Amazonas Territory, Venezuela (with José M. Cruxent in 1957), and in Dominica, British West Indies (1966). As they carried out their work in Latin America, it became increasingly clear to Cliff and Betty that there was a dire need to aid indigenous Latin American archaeologists in developing their scholarly skills and to provide frameworks within which long-term, broad-scale research programs could be developed. Here, Cliff's organizational and administrative abilities came to the fore.

Evans's efforts in this direction began with his election to the Institute of Andean Research in 1955 (Mason 1967:14). He served as a member of the Executive Board (1958-1960), and subsequently as President (1961-1964) and Vice-President (1965-1971). Under Institute auspices he organized a project, Interrelationships of New World Cultures, involving joint research by scholars from 10 institutions in Mexico, Panama, Columbia, Ecuador, and the United States. The project focused on the Formative period with special reference to cultural interrelationships between diverse regions and different environmental zones (1962a). He also assisted John V. Murra in organizing another Institute-sponsored project, Study of Inca Provincial Life.

Other steps to aid the development of Latin American archaeology began in 1961 when the Evanses and James Ford organized a seminar on quantitative pottery analysis at Barranquilla, Colombia, sponsored by the Smithsonian Institution, the National Science Foundation, the Organization of American States, and the Universidad del Atlántico. Its purpose was to establish a common, initial working typological system for Latin America and to bring young Latin American archaeologists together to become acquainted, to share ideas, and to establish an information network. 
A second major step was taken in October 1964. The Evanses organized a month-long training seminar for twelve Brazilian archaeologists and three students in Curitiba under the auspices of the Fulbright Commission, the Research Council of the University of Paraná, and the Smithsonian Institution. Out of the seminar, beginning in 1965, came a 5-year cooperative effort, the Brazilian National Program of Archeological Research (PRONAPA), cosponsored by the Brazilian Conselho Nacional de Pesquisas and the Smithsonian Institution, with the authorization and collaboration of the Brazilian Patrimônio Histórico e Artístico Nacional. The initial aims of the program were to establish a basic culture-history framework for Brazil, to develop training programs for Brazilian archaeologists in Brazil and abroad, to encourage Brazilian universities to support archaeological research, and to develop a high-level publication program in Portuguese to stimulate national interest in archaeology. Cliff, through the Smithsonian Institution, was able to provide critical logistics support (field vehicles, boats, motors, per diem, maintenance, supplies); the Brazilian entities provided publication support, released time for faculty research, etc. In 1968 Evans was able to report to the Smithsonian Institution that the grants for the first 3 years had been well used: only $4.1 \%$ of the funds had gone to overhead; the rest to research-a truly remarkable record. The initial 5-year program was very successful. With various changes the program has continued to the present and has been a major force in the development of archaeological research in Brazil. Subsequent projects focused on Amazonia, which Cliff helped to develop within the Smithsonian Institution, and include the Amazon Ecosystems Research Program and the Prehistoric Human Ecology of Amazonia project. In both instances Latin American scholars were actively involved in the research efforts. In 1968 the Evanses helped to establish a similar program for the Andes, Proyecto Andino de Estudios Arqueológicos, supported by the Wenner-Gren Foundation, the National Geographic Society, and the Smithsonian Institution.

Another research project in which Cliff was centrally involved was the initial attempt by Irving Friedman of the U.S. Geological Survey and others to develop the obsidian hydration dating method. Cliff was instrumental in providing obsidian samples from the Smithsonian collections and arranging loans from other museum collections. His and Betty's paper (1960f), together with a paper by Friedman and Smith (1960), laid the foundations for subsequent work on the method which, over the last 2 decades, has been refined and widely applied by numerous workers.

In addition to the undertakings discussed above, Cliff implemented numerous other successful projects. A count made in his files indicates he generated support for 40 research proposals during his 30-year career at the Smithsonian, probably a record for any of its scientists. His work within the Smithsonian resulted in the development of new research and research-support facilities.

In 1964, when the Bureau of American Ethnology and the Department of Anthropology were combined as the Office of Anthropology, Evans became a supervising curator with direct responsibility for the organization of the newly created Processing Laboratory. Under his leadership, the separate Archeology and Ethnology Laboratories and their staffs were quickly unified, and a series of standardized operating procedures were developed to enable museum specialists and technicians to process all collections and to store all specimens, thus freeing the curatorial staff of many detailed and routine activities. By 1967 this centralized facility had developed into an independent unit, administratively under the chairman, with Cliff continuing in an ever-decreasing advisory role. At that time, the Processing Laboratory also assumed responsibility for physical anthropology collections. Since 1967 all accessioning, cataloguing, storing, and lending of objects in anthropology have been efficiently handled by the unit which he successfully developed.

In 1970 Cliff was appointed Chairman of Anthropology with strong support from the curatorial staff, a position which he held for a 5-year term. He brought to this office the full measure of his considerable administrative talent, including his imagination and creativity, his idealism and common sense, his persistence and determination, and his vast knowledge of Smithsonian internal organization, its budget process and its people. Perhaps his most notable contribution as chairman was his anticipation of the need to develop large-scale research programs on broad thematic lines which could include individual research projects, thus assuring long-term funding from the 
Smithsonian budget. The first such program, the Paleoindian, Paleoecology, and Paleoenvironmental Research Program, implemented in 1972, was designed with broad applicability to the entire western Hemisphere. A second program, the previously noted Amazon Ecosystems Research Program, involving colleagues in Brazil as well as Smithsonian staff members in the fields of herpetology, ichthyology, entomology, ornithology, and botany, was inaugurated in 1974. Together with Edward Ayensu, then Chairman of the Department of Botany, Cliff developed a program in palynology, which generated contract funds for staff archeologists' research beginning in 1974 . The Bone Biology and Paleopathology Program, conceived and designed by Donald Ortner, received Cliff's active support in guiding it through Smithsonian channels.

Throughout his chairmanship, Cliff proved to be a vigorous fighter for anthropology at all levels of the Smithsonian in such matters as space, staffing, and funds for travel, equipment, and supplies. He was concerned with the efficient operation of all aspects of his department: the Processing Laboratory, the Conservation Laboratory, the Scientific Illustrators Group, and such basic general activities as staff publications, especially the Contributions to Anthropology series, and the exhibits program. He took a keen interest in the broad functions as well as the most minute details of all organizational operations, and he was able to maintain a perspective in weighting each activity. He was always available to everyone-curator, technician, and secretary-to discuss not only organizational and job-related problems but also personal matters, and the number of persons whom he aided in solving problems and in career advancement is legion..

Cliff was in all respects a model curator. With regard to collections, he considered them to be a precious resource, not only for exhibit purposes but also for present and future research on human cultural history in the broadest sense. From their own fieldwork, the Evanses added unique archaeological collections from many countries in South America, especially Brazil, Ecuador, Venezuela, and Guyana. Cliff's range of interest, however, went far beyond archaeology and Latin America. In 1952-1953, he and Betty made an important collection of ethnological specimens from the Wai-Wai Indians of the tropical forest of Guyana before almost total acculturation took place (1955a, 1966b, 1964e). Similarly, and largely through his organizational skills, the National Museum of Natural History received in 1976-1977 an enormous and extremely important collection of ethnological specimens representative of disappearing crafts and technologies from Iran, Pakistan, and Ceylon. This collection was made by a Smithsonian-sponsored research team, directed in the field by the late Hans Wulff, Donald Godden, and others of Australia. Through his responsiveness to the public, Evans throughout his career added important individual specimens and small groups of objects from Latin America to the National Collections. He was also interested in supplementing and correcting data on specimen catalogue cards, and in making collections available for study to visiting students and professional colleagues. He was very much concerned with the proper storage and conservation of artifacts, making sure that adequate storage units and trays were on hand, and fighting for funds for their purchase.

Cliff firmly believed in good didactic exhibits that communicate scientific knowledge to the public. In 1953-1954 when there were neither special funds for exhibits nor a large exhibits staff, he pioneered the modernization of exhibits in the Museum of Natural History with the development of a permanent exhibit, "Highlights of Latin American Archeology" (1956d). Later, in 1974-1975, he once again produced, with the assistance of Geoffrey Conrad, a new permanent exhibit entitled "South America: Continent and Culture." To this exhibit he brought a new concept, namely the integration of the human cultural response through time with the four major ecological zones in South America, the savanna, the Andean highlands, the Andean coast, and the tropical forest.

Cliff was diligent in his service to the public, as befits a curator in a largely tax-supported institution. During his early curatorial career he prepared numerous bibliographies on Latin American archaeology for public distribution. He also took seriously the responsibility of answering inquiries from the public, and the volume of his correspondence with persons in all stations of life, from elementary school children to the most learned colleague, was enormous. Even after a person was hired to deal with routine inquiries, he continued to handle a considerable number of the more difficult questions. In his reorganization of the Anthropology Processing Laboratory, he 
established a procedure whereby objects brought by the public for identification were held by the Laboratory staff and were examined by the appropriate curator at his convenience several times each week. He faithfully examined and reported on many such objects weekly, not only from Latin America and the mid-Atlantic region but also from elsewhere in North America when specialists in those cultural areas were unavailable.

Over the years Evans lent his administrative skills, good judgment, and scholarly acumen to numerous professional organizations and societies. He reviewed a vast number of research proposals for many granting organizations, was a member of the Executive Committee of the Society for American Archeology (1955-1956) and Treasurer of the Anthropological Society of Washington (1960-1965), served as a member of the National Advisory Board, Desert Research Institute, University of Nevada System (1971-1977), and of the Advisory Committee on Archeology of the Commission of the Maryland Geological Survey [1968-1971), including chairmanship. He was also a member of the Committee on Latin American Anthropology, Division of Behavioral Sciences, National Research Council, and of the Editorial Advisory Board for the Handbook of Middle American Indians from 1956 to 1966. Later (1970), he served on the NRC Behavioral Sciences Panel, evaluating applications in the National Science Foundation Graduate Fellowship Program. Other public service activities were as a member of $(1968-1981)$ of the Grenada National Trust, Grenada, Lesser Antilles, advising on protection of archaeological and historical sites and objects; and as U.S. representative (1959-1968) on the Subcommittee on Anthropology, Commission of History of the Instituto Panamericano de Geografía e Historia, serving as Subcommitee President (1959-1961). He was also an advisor on archaeology to the Centro de Antropología, Universidad de Panamá; and on the editorial board of the journal Hombre y Cultura (1966-1981). In addition, he served on the fellowship panel of the John Simon Guggenheim Memorial Foundation (1958-1961) and of the Organization of American States (1955-1959). In 1980 he was appointed to the Joint Committee on Landmarks of the National Capital and to the Scientific Advisory Board of the Walter Roth Museum of Archaeology and Anthropology. Particularly close to his professional concerns and interests were the purpose and interdisciplinary approach of the Association for Tropical Biology which he served as a member of its Editorial Advisory Board (1969-1971) and as Secretary-Treasurer from 1971 until his death. In 1979 he was primarily responsible, under difficult circumstances, for the organization and implementation of the Fifth International Symposium of the Association on "The Biological Model of Diversification in the Tropics"-a landmark "state of the science" event in tropical research held in Venezuela. Lastly, he served on the Society for International Law Panel on International Traffic in Archaeological and Art Objects (1969-1970). The problem of illegal trafficking in antiquities was a matter of concern to Evans throughout his professional career. His last official act, on the day of his death, was the examination of a U.S. Customs Bureau seizure of Peruvian artifacts at Dulles International Airport.

Cliff received numerous honors and awards during his career. He was a member of Phi Beta Kappa and was elected to the District of Columbia Chapter of the Society of Sigma Xi in 1971. He was an Honorary Life Member of both the Archeological Society of Maryland and the Archeological Society of Virginia and in 1980 was made an Honorary Member of the Sociedade de Arqueologia Brasileira. Betty and he received the Washington Academy of Sciences Award for Scientific Achievement in 1956 for their research in the Amazon and in 1966 they were awarded the 37th International Congress of Americanists Gold Medal for Distinguished Americanist Studies as well as the Orden Nacional al Mérito (Grado Oficial) by the government of Ecuador. In 1965 Cliff had received the Medal and Certificate of "Camara Casudo" for meritorious work in the field of international archaeology by the Instituto de Antropologia, Universidade do Rio Grande do Norte, Brazil.

Cliff's scholarly and administrative accomplishments were many, as his career and his bibliography attest, but he was also a very human and caring person. His acts of personal kindness and help to others, especially younger scholars, were manifold. Dozens of Latin American and North American scholars benefited in many ways from his aid and advice, "behind the scenes," to use one of his favorite expressions. His help was given out of both a professional concern for the 
enhancement of good scholarship and a personal concern and caring for individuals. Cliff's and Betty's home in Georgetown was always open to visitors from throughout the world. There guests experienced warm hospitality and lively conversation and were often taken to enjoy the restaurants and the performing arts of Washington. Both Cliff and Betty were active supporters of cultural organizations in the Capital.

Cliff was endowed with a great sense of humor. He loved anthropological cartoons, especially archaeological ones, which he collected and posted just outside his office for the amusement of passersby, indicating that, while he took science and research seriously, he was very aware of the provisional nature of our discoveries and recognized the perils of taking ourselves too seriously. Cliff appreciated good jokes, those told to him as well as those played on him and delighted in playing jokes on others, especially those who were similarly appreciative. For example, one of us (Van Beek) was greeted on return from the field by a well worn, stuffed gorilla, sitting in his desk chair, wearing glasses, and reading one of his offprints upside down.

Cliff cared greatly about the Smithsonian, both as a scientific organization and as a collection of people. He relished la política, as he called it, and took a puckish delight in happenings within the Smithsonian and the larger governmental setting in which it is enmeshed. He took strong, sometimes critical, stands in his roles as curator, administrator, and chairman of the Senate of Scientists. But his overriding concern was for the welfare and the purposes of the Institution. While he might criticize or gently chuckle at his and others' sometime foibles, he was the Smithsonian's staunchest supporter and an articulate and able spokesman for it. He particularly cared for the Smithsonian support staff - the guards, secretaries, librarians, and technicians who make the organization function. He quietly helped many people who had personal difficulties or who were caught in the labyrinthine Civil Service or institutional rules. He worked actively (and long before it was legally mandated) to support job acquisition and enhancement for minority group members within the Institution.

A memorial service for Cliff was held on February 27, 1981, in the Baird Auditorium of the National Museum of Natural History (Fiske et al. 1981), attended by several hundred persons. Speakers included colleagues and friends from throughout the western hemisphere. Official tributes came from Chile, Ecuador, and Panama. Other tributes from Latin American colleagues followed later, e.g., Núñez (1981). A portion of the Memorial Tribute by one of us (Sanoja) sums up much about Cliff:

Clifford Evans always had an open mind about people. What he appreciated most were the qualities of hard work, good organization, scientific proficiency and honesty. He found these qualities in many people in Latin America. Some had different ideological orientations than his, but he always considered more important the human and scientific qualifications of a person. When the political fortunes of a scientist changed, as they did in some countries, he was always there to give loyal support. . . He put all his affection and devotion into what he was doing and promoted a deep and warm solidarity among peoples of different countries [Fiske et al. 1981:17].

Cliff leaves his widow, Betty J. Meggers, and a brother, William, both of Washington, D.C.

A number of years ago, Cliff and Betty established a Latin American Archeology Fund within the Smithsonian to aid Latin American scholars-yet another of their many ways of helping others. Donations in Clifford Evans's name can be made through the Department of Anthropology, U.S. National Museum of Natural History, Smithsonian Institution, Washington, D.C. 20560.

Acknowledgment. We are especially indebted to Betty J. Meggers who reviewed and corrected Cliff's bibliography and provided published and unpublished documents on his life and career.

DON D. FOWLER

GUS W. VAN BEEK

MARIO SANOJA 


\section{REFERENCES CITED}

Fiske, Richard, et al.

1981 A memorial ceremony in honor of Clifford Evans (1920-1981), Baird Auditorium, National Museum of Natural History, Washington, D.C., Friday, February 27, 1981. (Ms. and tape on file, National Anthropological Archives, Smithsonian Institution, Washington, D.C.)

Friedman, Irving, and Robert L. Smith

1960 A new dating method using obsidian: Part I, the development of the method. American Antiquity 25:476-522.

Mason, J. Alden

1967 A brief history of the Institute of Andean Research, Inc., 1937-1967. Institute for Andean Research, New York.

Núñez, A. Lautaro

1981 Dr. Clifford Evans and Chilean archaeology. Chilean University Life 10:7-8.

Payne, Alma S.

1968 Surveyors of extinct cultures. Betty J. Meggers, Clifford Evans. In Partners in Science, pp. 17-38. World, Cleveland.

Poole, Lynn, and Gary Poole

1963 Betty J. Meggers and Clifford Evans. In Scientists Who Work Outdoors, pp. 146-160. Dodd, Mead, New York.

\section{BIBLIOGRAPHY OF CLIFFORD EVANS}

1947 Review of Excavation in northern Chile, by Junius B. Bird. American Antiquity 12:278-279.

1948 Review of Skeletal material from the central coast of Peru, by Marshall T. Newman. American Antiquity 14:68-69.

1950a A report on recent archaeological investigations in the Lagôa Santa Region (Minas Gerais). American Antiquity 15:341-343.

$1950 \mathrm{~b}$ Book note on The pre-history of the Lagôa Santa Region (Minas Gerais). American Anthropologist 52:108.

1950c (With Betty J. Meggers) Preliminary results of archaeological investigations in the mouth of the Amazon. American Antiquity 16:1-9.

1950d The archaeology of the Territory of Amapá (Brazilian Guiana). Ph.D. dissertation, Columbia University. University Microfilms (No. 1742), Ann Arbor.

1951a Review of Surface survey of Virú Valley, Peru, by James A. Ford and Gordon R. Willey. American Antiquity 16:270-272.

$1951 \mathrm{~b}$ (With Betty J. Meggers) American table d'hôte. Américas (English edition) 3:16-19.

1951c (With Betty J. Meggers) Cardápio americano. Américas (Portuguese edition) 3:16-19.

1951d (With Betty J. Meggers) La Mesa americana. Américas (Spanish edition) 3:16-19.

1951e (With Betty J. Meggers) Review of The pottery of Marajó Island, Brasil, by Helen C. Palmatary. American Anthropologist 53:396-398.

$1951 \mathrm{f}$ The territory of Amapá: land in dispute. Archaeology 4(3):175-180.

1952 (With William Duncan Strong) Cultural stratigraphy in the Virú Valley, northern Peru: the Formative and Florescent epochs. Columbia Studies in Archaeology and Ethnology 4. New York.

1953 (With C. G. Holland and Betty J. Meggers) The East Mound. Quarterly Bulletin of the Archaeological Society of Virginia $7(3)$.

1954a (With Betty J. Meggers) Uma interpretação das culturas da llha de Marajó. Instituto de Antropologia e Etnologia do Pará, Museu Goeldi, Publicação No. 7. Belém, Pará, Brazil.

1954b Review of Amazon Town: a study of man in the tropics, by Charles Wagley. American Anthropologist 56:508-510.

1954c Letter to editor re Spaulding's review of Ford's Measurement of Some Prehistoric Design Developments in the Southeastern States. American Anthropologist 56:114.

1955a (With Betty J. Meggers) Life among the Wai Wai Indians. National Geographic Magazine 107:329346.

1955b (With Betty J. Meggers) The Wai Wai of Guiana. In National Geographic on Indians of the Americas. pp. 345-355. National Geographic Society, Washington, D.C.

1955c New archeological interpretations in northeastern South America. In New interpretations of aboriginal American culture history. 75th Anniversary Volume of Anthropological Society of Washington, D.C., pp. 82-94.

1955d A ceramic study of Virginia archeology. Bureau of American Ethnology, Bulletin 160.

1955e (With Betty J. Meggers) Resumenes-las culturas de Marajó. Panamerican Union, Ciencias Sociales 6(32):116-121.

1955f Review of Jungle quest, by Edward Weyer. Américas 7(7):40-41 (English edition); [Spanish edition 7[8):41-42; Portuguese edition 7(8):41-42.] 
1955g Review of Paracas fabrics and Nazca needlework, 3rd century B.C.-3rd century A.D., by Junius Bird and Louisa Bellinger. The Scientific Monthly 81(3):150-151.

1955h (With Betty J. Meggers) Preliminary report on archeological investigations in the Guayas Basin, Ecuador. Cuadernos de Historia y Arqueología, Año IV, Vol. IV, Diciembre de 1954, No. 12:1-12. Guayaquil.

$1955 i$ (With Betty J. Meggers) Informe preliminar sobre las investigaciones arqueológicas reliazades en la cuenca del Guayas, Ecuador. Cuadernos de Historia y Arqueología, Año IV, Vol. IV, Diciembre de 1954, No. 12:1-18. Guayaquil.

1955j (With Betty J. Meggers) Preliminary results of archeological investigations in British Guiana. Timehri: The Journal of the Royal Agricultural and Commercial Society of British Guiana 34:5-26.

1955k Filiaçōes das culturas arqueológicas no Territorio do Amapá. Anais do XXXI Congreso Internacional de Americanistas, São Paulo 2:801-812.

19551 (With Betty J. Meggers) Preliminary results of archaeological investigations in British Guiana (abstract). Anais do XXXI Congreso Internacional de Americanistas, São Paulo 2:761-762.

$1955 \mathrm{~m}$ (With Betty J. Meggers) Culture areas of South America: an archeological point of view (Abstract). Anais do XXXI Congreso Internacional de Americanistas, São Paulo, 2:683-684.

1956a Review of Proto-Lima: a Middle period culture of Peru, by A. L. Kroeber. American Anthropologist 58:204-205.

1956b (With Junius B. Bird) Review of Ancient arts of the Andes and thirty-two masterworks of the Andes. a supplement, by Wendell C. Bennett. American Antiquity 21:438-439.

1956c Tendencias actuales de la investigación arqueológica en América Latina. Panamerican Union, Ciencias Sociales 7(38):85-95.

1956d The culture area concept in an exhibition of Latin American archaeology, United States National Museum, Washington. (Text in English and French.) UNESCO Museum 9(4):215-225.

1956e (With Betty J. Meggers) The reconstruction of settlement pattern in the South American tropical forest. In Prehistoric settlement patterns in the New World, edited by G. R. Willey. Viking Fund Publications in Anthropology 23:156-164.

1957a (With Betty J. Meggers) Formative Period cultures in the Guayas Basin, coastal Ecuador. American Antiquity 22:235-247.

1957b Review of Program of the history of America, Indigenous period. American Antiquity 22:306-309. [Spanish translation printed in Revista del Museo Nacional, Tomo 26:299-302, 1958.]

1957c Review of Culturas precolombinas de Chile, by Greta Mostny. Hispanic American Historical Review 37:111.

1957d Review of Cultura diaguita chilena y cultura de el Molle, by F. L. Cornely. Hispanic American Historical Review 37:110.

1957e (Contributing editor, with Betty J. Meggers) Archeology of western and southern South America. Handbook of Latin American Studies 19:24-36.

$1957 \mathrm{f}$ (With Betty J. Meggers) Archeological investigations at the mouth of the Amazon. Bureau of American Ethnology, Bulletin 167. Washington, D.C.

$1957 \mathrm{~g}$ Review of A history of the ancient Southwest, by Harold S. Gladwin. American Scientist, 45:394A.

1958a Review of Peru, by G. H. S. Bushnell. American Antiquity, 23:328-329.

1958 b (With Betty J. Meggers) La mesa americana. Revista de información y cultura Michoacan (January

1958) 41:6-9. [Reprinted from the Spanish edition of Américas, August, 1951, without credit to source.]

1958c Archeology: western hemisphere. The Americana Annual 1958:42-44. Americana Corp., New York.

1958d (With Betty J. Meggers) Archaeological research in eastern Ecuador: report to the Committee on

Research (Grant no. 2012, 1956) Yearbook 1957, American Philosophical Society: 376-377.

1958e (With Betty J. Meggers) Valdivia-an Early Formative culture of Ecuador. Archaeology 11(3): 175-182.

1958 f (With Betty J. Meggers) Archaeology: South America (except Colombia and Venezuela). In Handbook of Latin American Studies 20:25-35.

1958g (Compiler and editor) Anthropological activities in the United States-1956. Boletín Bibliográfico de Antropología Americana 19-20 (Pt. 1, 1956-57):31-65. Mexico City.

1958h Review of The archeology of central and southern Honduras, by Doris Z. Stone. American Journal of Archaeology 62:461-462.

1958i Comments on Rydén's review of Heyerdahl and Skjölsvold, Archaeological evidence of pre-Spanish visits to the Galápagos Islands. American Antiquity 24:189.

1958j (With Betty J. Meggers) Review of Method and theory in American archaeology, by Gordon R. Willey and Philip Phillips. American Antiquity 24:195-196.

1958k (With Betty J. Meggers) Archeological evidence of a prehistoric migration from the Rio Napo to the mouth of the Amazon. In Migrations in New World culture history. University of Arizona Social Science Bulletin No. 27, 19(2):9-16.

1958l Review of The marches of El Dorado: British Guiana, Brazil, Venezuela, by Michael Swan. Hispanic American Historical Review 38:570.

$1958 \mathrm{~m}$ (With Betty J. Meggers) Present status and future problems of archeological investigations in Ecua- 
dor. In Miscellanea Paul Rivet Octogenario Dictata, Vol. 2:353-361. Universidad Nacional Autónoma de México.

1958n (With Betty J. Meggers) Identificação das áreas culturais e dos tipos de cultura na base da cerâmica das jazidas arqueológicas. Arquivos do Museu Nacional 46:9-32. Rio de Janeiro.

1959a Archeology: western hemisphere. In The Americana Annual 1959, pp. 44-45. Americana Corp., New York.

1959b (With Betty J. Meggers and Emílio Estrada) Cultura Valdivia. Publicación del Museu "Victor Emílio Estrada" 6. Guayaquil.

1959c Review of Etnologia brasileira (Fulniō-os últimos Tapuias), by Estavão Pinto. Hispanic American Historical Review 39:340-341.

1959d Review of Samatari (Orinoco-Amazoni), by Alfonso Vinci. Hispanic American Historical Review 39:358-359.

1959e Review of Hiléia amazonica: aspectos da flora, fauna, arqueologia e etnografia indigenas, third ed., by Gastão Cruls. Hispanic American Historical Review 39:482.

1959f Review of Manual de la cerámica indigena, by Antonio Serrano. Hispanic American Historical Review, 39:483.

1959g (With Betty J. Meggers) O emprêgo do método comparativo na interpretação arqueológica. Revista Sociologia 20:397-409. São Paulo.

1959h (With Betty J. Meggers) Archaeology: South America (except Colombia and Venezuela). In Handbook of Latin American Studies 21:16-26.

1960a Inca. In The World Book Encyclopedia, 1960, pp. 79-82. Chicago.

1960b (With George Quimby) American Indian. In The World Book Encyclopedia, 1960, pp. $108-139$. Chicago.

1960c Archaeology: western hemisphere. The Americana Annual 1960:43-45. Americana Corp., New York.

$1960 \mathrm{~d}$ (With Betty J. Meggers and José M. Cruxent) Preliminary results of archeological investigations along the Orinoco and Ventuari rivers. Actas del XXXIII Congreso Internacional de Americanistas, San José, Costa Rica, 1958:359-369.

1960e (With Betty J. Meggers) Archeological investigations in British Guiana. Bureau of American Ethnology, Bulletin 177.

1960 (With Betty J. Meggers) A new dating method using obsidian, Part II. An archaeological evaluation of the method. American Antiquity 25:523-537.

$1960 \mathrm{~g}$ Review of Native peoples of South America, by Julian H. Steward and Louis Faron. American Antiquity 26:123-124.

$1960 \mathrm{~h}$ Review of The archeology of the lower Tapajós Valley, Brazil, by Helen C. Palmatary, The Hispanic American Historical Review 40:628-629.

1960i Review of A jazida José Vieira: um sitio Guaraní e pre-cerâmico do interior do Paraná, by Annette Laming and José Emperaire. American Antiquity 26:292-293.

1960j (Assistant editor) Guianas, Ecuador, and Brazil. Abstracts of New World Archaeology 1:104-106, 109-111.

1960k (Contributing editor, with Betty J. Meggers) Archaeology: South America (except Colombia and Venezuela.) Handbook of Latin American Studies 22:17-26.

1961a Review (Spanish translation) of Native Peoples of South America, by Julian H. Steward and Louis Faron. Revista Interamericana de Ciencias Sociales (Segunda epoca) 1(1):219-220.

1961b Review of O sambaquí do Macedo, A.52.B-Paraná, Brasil, by Wesley R. Hurt and Oldemar Blasi. American Antiquity 27:122-123.

1961c Review of Ecuador 1960: Verslag van een Archaeologische Studiereis, by Hans Feriz. American Antiquity 27:262-263.

1961d (Assistant editor) Guianas, Ecuador and Brazil. Abstracts of New World Archaeology 2:156-159, 162-164.

1961e (Contributing editor, with Betty J. Meggers) Archaeology: South America (except Colombia and Venezuela). Handbook of Latin American Studies 23:24-37.

$1961 f$ (Contributing editor, with Michael J. Harner) Ethnology: South America. Handbook of Latin American Studies 23:42-57.

$1961 \mathrm{~g}$ Review of An archeological chronology of Venezuela (2 vols.), by José Cruxent and Irving Rouse. American Journal of Archaeology 65:88-89.

$1961 \mathrm{~h}$ (With Betty J. Meggers) Review of Spanish translation of Method and theory in American archeology, by Gordon R. Willey and Philip Phillips. Revista Interamericano 1(1):220-222.

$1961 \mathrm{i}$ (With Betty J. Meggers) An experimental formulation of horizon styles in the tropical forest area of South America. In Essays in Pre-Colombian art and archaeology, by Samuel K. Lothrop et al., pp. 372-388. Harvard University Press, Cambridge.

1962a (With Gordon Ekholm) The interrelationships of New World cultures: a coordinated research program of the Institute of Andean Research. In Akten des 34 Internationalen Amerikanistenkongresses, Wien, 1960, pp. 253-278. 
1962b (With Emílio Estrada and Betty J. Meggers) Possible transpacific contact on the coast of Ecuador. Science 135:371-372.

1962c Review (in Spanish) of Etnología y arqueología, Lima, 1960. Actas y trabajos del epoca prehispánica del Segundo Congreso Nacional de Historia del Perú (Lima, 1959), and Antiguo Perú, espacio y tiempo (Lima, 1960). Revista Interamericana de Ciencias Sociales (Segunda epoca) 1(3):435.

1962d Review (in Spanish) of Los Charruas: síntesis etnográfica y arqueológica del Uruguay, Montevideo, 1960, by Serafín Cordero. Revista Interamericana de Ciencias Sociales (Segunda epoca) 1(3):437.

1962e (With Betty J. Meggers) Use of organic temper for carbon dating in lowland South America. American Antiquity, 28:243-245.

$1962 f$ (Contributing editor, with Betty J. Meggers) Archaeology: South America (except Colombia and Venezuela). Handbook of Latin American Studies 24:27-39.

1962g (With Betty J. Meggers) The Machalilla Culture: an Early Formative complex on the Ecuadorian coast. American Antiquity 28:186-192.

1963a (With Emílio Estrada) Cultural development in Ecuador. In Aboriginal cultural development in Latin America: an interpretative review. Smithsonian Miscellaneous Collections 146(1):77-88.

1963b (Editor, with Betty J. Meggers) Aboriginal cultural development in Latin America: an interpretative review. Smithsonian Miscellaneous Collections 146[1), Publication 4517.

19634C (Contributing editor, with Betty J. Meggers) Archaeology: South America (except Colombia and Venezuela). Handbook of Latin American Studies 25:26-34.

1964a Review of Edición extraordinaria en homenaje al cincuentenario del descubrimiento de Machupicchu: Revista del Museo e Instituto Arqueológico, Universidad Nacional del Cuzco. American Antiquity 29:398.

1964b Review of A preceramic settlement on the central coast of Peru: Asia, Unit 1, by Frederick Engel. American Anthropologist 66:197-198.

1964c Lowland South America. In Prehistoric man in the New World, edited by Jesse D. Jennings and Edward Norbeck, pp. 419-450. University of Chicago Press.

1964d Review of The Accokeek Creek site, a middle Atlantic seaboard culture sequence, by Robert L. Stephenson and Alice L. L. Ferguson. American Anthropologist 66:446-447.

1964e (With Betty J. Meggers) Genealogical and demographic information on the Wai Wai of British Guiana. In Beiträge zur Völkerkunde Südamerikas, Festgabe für Herbert Baldus zum 65 Geburtstag, edited by Hans Becher, pp. 199-207. Völkerkundliche Abhandlungen Band I, Des Niedersächsischen Landesmuseum Abteilung für Völkerkunde. Hanover.

$1964 f$ Review of Arqueología cronológica de Venezuela, by José M. Cruxent and Irving Rouse. The Hispanic American Historical Review 44:269-270.

$1964 \mathrm{~g}$ Review of Archaeological techniques for amateurs, by Philip C. Hammond. American Antiquity 30:126-127.

1964h (With Betty J. Meggers) British Guiana archaeology: a return to the original interpretations. American Antiquity 30:83-84.

1964i Review of The Norse Atlantic saga, being the Norse voyages of discovery and settlement to Iceland, Greenland, America, by Gwyn Jones. American Anthropologist 66:948-949.

1964j (With Emílio Estrada and Betty J. Meggers) The Jambeli Culture of south coastal Ecuador. Proceedings of the U.S. National Museum 115(3492):483-558.

1964k Review of Archaeology of the Diquis Delta, Costa Rica, by S. K. Lothrop. American Anthropologist 66:1218.

19641 (With Betty J. Meggers) Review of Venezuelan archaeology, by Irving Rouse and José Cruxent. American Antiquity 30:227-228.

1964m Review of Pre-Colombian architecture, by Donald Robertson. American Anthropologist 66:1441.

1964n (With Betty J. Meggers) Especulaciones sobre rutas tempranas de difusión de la cerámica entre Sur y Mesoámerica. Hombre y Cultura 1(3):1-15.

1965a Review of Treasures of ancient America: the arts of Pre-Colombian civilizations from Mexico to Peru, by S. K. Lothrop. American Anthropologist 67:159-160.

1965b Review of Andes 2, Excavations at Kotosh, Peru, by Seiichi Izumi and Toshihiko Sono. American Anthropologist 67:160-162.

1965c (With Betty J. Meggers) Cronología relativa y absoluta en la costa del Ecuador. Cuadernos de Historia y Arqueología, Año XI 1961(27):3-8. Casa de la Cultura Ecuatoriana, Núcleo del Guayas, Guayaquil.

1965d Review of Ancient ruins and archaeology, by L. Sprague de Camp and Catherine C. de Camp. ISIS $56(2): 184-236$.

1965e Guia para prospeção arqueológica do Brasil. Museu Paraense Emílio Goeldi, Guia No. 2. Belém.

1965f (With Emílio Estrada and Betty J. Meggers) Early Formative period of coastal Ecuador: the Valdivia and Machalilla phases. Smithsonian Contributions to Anthropology, Vol. 1.

1965g The dating of Easter Island archeological obsidian specimens: Report No. 18. In Reports of the Norwegian archaeological expedition to Easter Island and the east Pacific, Vol. 2-Miscellaneous Reports. Monographs of the School of American Research and the Kon-Tiki Museum 24(2):469-495. 
1965h (Contributing editor, with Betty J. Meggers) Archaeology: South America. Handbook of Latin American Studies 27:56-75.

1966a (With Betty J. Meggers) A transpacific contact in 3000 B.C. Scientific American 214(1):28-35.

1966b Review of Homaneje a Fernando Márquez-Miranda, arqueólogo e historiador de América. American Antiquity 31:593-594.

1966c (With Betty J. Meggers) Mesoamerica and Ecuador. Handbook of Middle American Indians 4:243264.

1966d (With Betty J. Meggers) Transpacific origin of Valdivia Phase pottery on coastal Ecuador. Actas y Memorias, XXXVI Congreso Internacional de Americanistas, España 1964 1:63-67. Seville.

1966e (With Betty J. Meggers) Beginnings of food production in Ecuador. Actas y Memorias, XXXVI Congreso Internacional de Americanistas España, 1964 1:201-207. Seville.

1966 (With Betty J. Meggers) A transpacific contact in 3000 B.C. Japan-America Forum 12(6):44-57. (Japanese translation of 1966a.)

1967a Review of Ancient arts of the Americas, by G. H. S. Bushnell. American Antiquity 32:255-256.

1967b Introdução. In Programa Nacional de Pesquisas Arqueológicas: resultados preliminares do primeiro ano 1965-1966. Museu Paraense Emílio Goeldi, Publs. Avulsas 6:7-13. Belém.

1967c Amazon archeology-a centennial appraisal. Actas do Simpósio sôbre a Biota Amazônica 2:1-12. Rio de Janeiro.

1967d (Contributing editor, with Betty J. Meggers) Archaeology: South America. Handbook of Latin American Studies 29:75-104.

1967e (With Betty J. Meggers) Potsherd language and how to read it. Smithsonian Institution, Washington, D. C. (Multilith.)

1968a The lack of archeology on Dominica. In Proceedings of the Second International Congress for the Study of Pre-Columbian Cultures in the Lesser Antilles, Barbados, pp. 93-102. Barbados Museum.

1968b Obituary of Rafael Larco Hoyle, 1901-1966. American Antiquity 33:233-236.

1968c Obituary of James Alfred Ford, 1911-1968. American Anthropologist 70:1161-1167.

$1968 \mathrm{~d}$ Archeology and diplomacy in Latin America. Foreign Service Journal 45:35-37, 50.

1968e (With Irving Friedman) Obsidian dating revisited. Science 162:812-814.

$1968 f$ (With Betty J. Meggers) Archeological investigations on the Rio Napo, eastern Ecuador. Smithsonian Contributions to Anthropology, Vol. 6.

1969a Review of Daily life in ancient Peru, by Hans Dietrich Disselhoff. American Antiquity 34:97-98.

1969b Introdução. Programa Nacional de Pesquisas Arqueológicas, resultados preliminares do segundo ano, 1966-67. Museu Paraense Emílio Goeldi, Publs. Avulsas 10:7-10. Belém.

1969c (With Betty J. Meggers) Como interpretar el lenguaje de los tiestos. (Translated by Víctor A. Núñez Regueiro from revised edition of Potsherd language, 1967.) (Multilith).

1969d (With Betty J. Meggers) Introdução. Programa Nacional de Pesquisas Arqueológicas. Resultados preliminares do terceiro ano, 1967-68. Museu Paraense Emílio Goeldi, Publs. Avulsas 13:7-11. Belém.

1969e (With Jose Proenza Brochado et al.) Arqueologia Brasileira em 1968: um relatorio preliminar sôbre o Programa Nacional de Pesquisas Arqueológicas. Museu Paraense Emílio Goeldi, Publs. Avulsas 12:1-33. Belém.

1969 (With Betty J. Meggers) Speculations on early pottery diffusion routes between South and Middle America. Biotropica 1:20-27.

1970a (With Jose Proenza Brochado et al.) Brazilian archaeology in 1968: an interim report on the National Program of Archaeological Research. American Antiquity 35:1-23.

1970b (With Betty J. Meggers) Como interpretar a linguagem da cerâmica (translated by Alroino B. Eble from the revised edition of Potsherd language, 1967.) (Multilith.)

1970c (Contributing editor, with Betty J. Meggers) Archaeology: South America. Handbook of Latin American Studies, 31:68-94.

$1970 \mathrm{~d}$ Review of Bibliografía indigena andina peruana (1900-68) (2 vols.), by Hector Martinez, Miguel Cameo C., and Jesus Ramirez S. Lima. American Anthropologist 72:640.

1971a (With Betty J. Meggers) Introdução. Programa Nacional de Pesquisas Arqueológicas. Resultados preliminares do quarto ano, 1968-69. Museu Paraense Emílio Goeldi. Publs. Avulsas 15:7-9. Belém.

1971b Review of The upper Amazon, by Donald Lathrap. American Anthropologist 73:1414-1416.

1971c (With Betty J. Meggers) Especulaciones sobre rutas tempranas de difusión de la cerámica entre sur y mesoamérica. Revista Dominicana de Arqueología y Antropología, Año 1 1(1):137-149. (Translation of 1969e.)

1971d (Contributing editor, with Betty J. Meggers) Archaeology: South America. Handbook of Latin American Studies 33:67-102.

1973a (With Betty J. Meggers) A reconstituição da pré-histôria amazônica. Algumas considerações teóricas. In O Museu Goeldi no Ano do Sesquicentenário. Museu Parense Emílio Goeldi, Publs. Avulsas 20:51-69. Belém.

1973b (With Betty J. Meggers) Site survey at the mouth of the Amazon. [Reprint from 1957f:6-11.] In In Search of Man, edited by Ernestene L. Green, pp. 43-48. Little, Brown, Boston. 
1973c (With Betty J. Meggers) United States "imperialism" and Latin American archaeology. American Antiquity 38:257-258.

1973d (With Betty J. Meggers) An interpretation of the cultures of Marajó Island. [Revised English translation of 1954a.] In Peoples and cultures of native South America, edited by Daniel R. Gross, pp. 39-47. Natural History Press, New York.

1973e (Contributing editor, with Betty J. Meggers) Archaeology: South America. Handbook of Latin American Studies 35:49-69.

1974a Review of Public archeology, by Charles R. McGimsey III. Museum News 52(8):49-50.

1974b (With Betty J. Meggers) Introdução. Programa Nacional de Pesquisas Arqueológicas. resultados preliminares do quinto ano, 1969-70. Museu Parense Emílio Goeldi, Publs. Avulsas 26:7-10. Belém.

$1974 \mathrm{c}$ (With Betty J. Meggers) Imperialismo norteamericano y arqueología latino-americána. [Translation of 1973c.] Boletín del Instituto Montecristeño de Arqueología 1:11-13. Montecristi, República Dominicana.

1974d (With Betty J. Meggers) A transpacific contact in 3000 B.C. In New World Archaeology: Theoretical and Cultural Transformations, edited by Ezra B. W. Zubrow, Margaret C. Fritz, and John M. Fritz, pp. 97-104. Freeman, San Francisco. [Reprint of 1966a.]

$1974 \mathrm{e}$ (With Betty J. Meggers) A reconstituição da pré-história amazônica: algumas considerações teóricas. Paleoclimas 2, Instituto de Geografia, Universidad de São Paulo. [Reprint of 1973a.]

1975a (With Betty J. Meggers) La "seración Fordiana" como método para construir una cronología relativa. Revista de la Universidad Católica 3(10):11-40. Quito.

1975b (Contributing editor, with Betty J. Meggers) Archaeology: South America. Handbook of Latin American Studies 37:52-84.

1976a (With Betty J. Meggers) Some potential contributions of Caribbean archaeology to the reconstruction of New World prehistory. In Proceedings of the First Puerto Rican Symposium in Archaeology, edited by Linda Sickler Robinson, pp. 25-32. Informe No. 1, Fundación Arqueológica, Antropológica e Histórica de Puerto Rico.

1976b (With Betty J. Meggers) Background and introduction for symposium on New research designs applied to Paleoindian problems: some preliminary results. Actas del XLI Congreso Internacional de Americanistas, Mexico 3:458-461.

1976c (With Owen S. Rye) Traditional pottery techniques of Pakistan: field and laboratory studies. Smithsonian Contributions to Anthropology, No. 21.

1977a(With Betty J. Meggers) Early Formative period chronology of the Ecuadorian coast: a correction. American Antiquity 42:266.

1977b (With Betty J. Meggers) Las tierras bajas de Suramérica y las Antillas. Estudios Arqueológicos (Centro de Investigaciones Arqueológicas), Ediciones de la Universidad Católica, Quito, pp. 11-69. [Spanish translation of 1978c.]

1977c (Contributing editor, with Betty J. Meggers) Archaeology: South America. Handbook of Latin American Studies 39:73-109.

1978a (With Betty I. Meggers) Accomplishments of the proyecto andino de estudios arqueológicos, 1967-71. National Geographic Society Research Reports 1969:163-171.

1978c (With Betty J. Meggers) Lowland South America and the Antilles.' In Ancient Native Americans. edited by Jesse D. Jennings, pp. 543-591. Freeman. San Francisco.

1978d (With Betty J. Meggers) Aspectos arqueológicos de las tierras bajas de Suramérica y las Antillas. Cuadernos del Cendia 258(4). Universidad Autónoma de Santo Domingo. [Spanish translation of 1978c.]

1978e (With Betty J. Meggers) Ápresentação. Areas de Amazônia legal Brasileira para pesquisa e cadastro de sitios arqueológicos, by Mario F. Simões and Fernanda Araujo Costa. Museu Parense Emílio Goeldi, Publs. Avulsas 30:5. Belém.

1979 (With Betty J. Meggers) An experimental reconstruction of Taruma village succession and some implications. In Brazil: anthropological perspectives, edited by Maxine L. Margolis and William E. Carter, pp. 39-60. Columbia University Press, New York.

1980a (Contributing editor, with Betty J. Meggers) Archaeology: South America. Handbook of Latin American Studies 41:68-106.

$1980 \mathrm{~b}$ (With Betty J. Meggers) Un metodo cerámico para el reconocimiento de comunidades prehistóricas. Boletín del Museo del Hombre Dominicano 9(14):57-73.

In Press (With Betty J. Meggers) Lowland South America and the Antilles. In Ancient South Americans, edited by Jesse D. Jennings. Freeman, San Francisco. (Revision of 1978.)

In Press (Contributing editor, with Betty J. Meggers) Archaeology: South America. Handbook of Latin American Studies 43. 